\title{
Analysis of Employee Competency Development at the Corporate Headquarters of Makassar Raya Makassar City Market
}

\author{
Jumalia Mannayong1, Haerul ${ }^{2}$ \\ ${ }^{1}$ Sekolah Tinggi Ilmu Administrasi Negara Makassar \\ ${ }^{2}$ Universitas Negeri Makassar \\ E-mail:jumalia_M@yahoo.com
}

\begin{abstract}
In assessing the success of an agency, it can be seen from the human resources that drive the agency itself. The purpose of this study was to determine the development of employee competencies. This study uses descriptive qualitative methods using data collection methods, namely interviews, document review, and observation. The data collection instruments used were interview guidelines, document review guidelines, and observation guidelines as well as data analysis techniques by reducing data presentation, drawing conclusions, and verification. After that test the validity of the data with triangulation techniques. The results of this study indicate that overall employee competency development is in the good category. Regarding employee competency development at the Makassar Raya Regional Makassar Regional Office Corporate Office, reviewed from the Motif, Character, Self-Concept, Knowledge, and Skills aspects, but there are still some indicators that need to be improved to maximize the development of employee competence at the Regional Makassar Regional Office. Makassar Raya.
\end{abstract}

Keywords: Analysis, competence, employees

\section{INTRODUCTION}

Human resources is a strategic field of organization (Ayu, Niswaty, Darwis, \& Arhas, 2019; Niswaty, Juniati, Darwis, Salam, \& Arhas, 2019). Human resource management must be seen as an extension of the traditional view to managing people effectively and to require knowledge of human behavior and the ability to manage it. Various opinions about the understanding of human resource management, including the existence of creating human resources, there are interpreting it as manpower management and there are equating with the understanding of human resources with personal (personnel, staffing, etc.), but in resource management, human resources that may be appropriate are human resources management, thus simply understanding the management of human resources is managing human resources. The issue of the need to obtain superior and professional Human Resources that are expected by many business entities in Indonesia both public and private business entities to be able to compete in the era of globalization is often just a wishful thinking (Awaliah, Amirullah, \& Saleh, 2015; Erawati, Darwis, \& Nasrullah, 2017; Sari, Jamaluddin, Saleh, \& Arhas, 2020)

A large amount of Human Resources development funds have been expended for this purpose, but often results in disappointment. Efforts to increase the competence of Human Resources will be difficult when the method used forgets the role of the human brain as the central driving motor of human work, in this case, can be done using the reframing approach. The reframing approach is a shift in the organization's conception of how an organization can achieve its goals. The specific characteristics of this approach emphasize that efforts to create 
competencies in Human Resources within the organization must be carried out when the efforts made are able to open the mindset of Human Resources in the organization.

The importance of competence in public and private organizations is needed especially to answer the demands of the organization, where there is a very rapid change, the development of very complex and dynamic problems and future uncertainty in the order of people's lives (Alvesson, 2001; Pramularso, 2018; Sung \& Choi, 2014). Competence is an ability based on skills and knowledge that is supported by work attitudes and their application in carrying out their duties and work in a place that refers to specified work requirements. Increased skills and knowledge are strategies directed at increasing efficiency, effectiveness and capture attitudes in the context of improving organizational performance, while the dimensions can be in the form of efforts to develop human resources, organizational knowledge and institutional reform in dealing with the influence of organizational environment, according to the readiness of resource organizations Organizational people have the ability to answer these challenges by showing their performance through activities in the field of tasks and work within the organization (Gupta \& Singhal, 1993; Gylfason, 2001; Sanders, 2006).

Along with increasingly fierce competition due to rapid technological changes and a drastic environment on aspects of human life, every organization needs competent human resources to be able to provide satisfying service (customer satisfaction), but also value-oriented (customer value) so that the organization is not merely pursuing the achievement of high work productivity, but more on the performance in the process of achieving it (Denhardt \& Denhardt, 2015; Osborne, Radnor, \& Nasi, 2013; Perry \& Wise, 2006). The performance of each activity and individual is the key to achieving productivity because performance is an outcome in which people and other resources in the organization together bring the final results based on the quality level and standards that have been set. The consequence is that organizations need human resources who have unique skills and abilities in accordance with the organization's vision and mission.

For this reason, human resources in an organization must be seen as a major factor and treated as assets that receive the most critical priority, because humans are the only factors that move the wheels of the organization and as the main force to develop the organization. Improving the quality of human resources becomes very important and needs to be done in a planned, directed, and sustainable manner in order to improve capability and professionalism. Human resources in agencies need to be professionally managed so that a balance is reached between the needs of employees with the demands and capabilities of the organization. The goal of developing the quality of human resources is to improve the operational performance of employees in carrying out their duties. In addition, the high quality of human resources will lead to the birth of strong commitments in the completion of routine tasks according to their respective responsibilities and functions more efficiently, effectively and productively.

Professional human resource management arrangements, employees are expected to work productively. This professional management of employees must be started as early as possible namely from the recruitment of employees, selection, classification, placement of employees according to their abilities, expertise, skills and career development so that it makes it easier to allocate employees based on their capabilities. Employees are the main capital in an organization, both government and private organizations. It is said that it is the principal capital in an organization because the success of an organization in achieving its objectives depends on the employee who leads in carrying out the tasks that exist in the organization. 
The discussion of human resource development can actually be seen from two aspects, namely quantity, and quality (Carefoot, 1990; Gabcanova, 2012; Resources, 2011). The definition of quantity concerns the number of human resources. The number of human resources without being accompanied by good quality will become an organizational burden. While the quality, regarding the quality of human resources concerning abilities, both physical abilities and non-physical abilities (intelligence and mental), therefore for the sake of accelerating the main tasks and functions of any organization, improving the quality of human resources is one of the main requirements. The quality of human resources that involves two aspects, namely physical aspects (physical quality) and non-physical (non-physical quality) which involve the ability to work, think, and other skills, therefore, efforts to improve the quality of human resources can be directed at both aspects. So education and training efforts are needed. This effort is intended for the development of human resources.

Makassar Raya Makassar Regional Regional Corporation is a Regional-Owned Enterprise that has the task of attracting retribution services in every market in Makassar City which is managed directly by Makassar Raya Makassar Regional Regional Company. Every Market managed by Makassar Raya Makassar City Region Company consists of the Head of Market, board, staff, collector, cleaners, and security. The author, in this case, focuses on existing competencies in employees by observing through their educational experience and skills and years of service. According to preliminary observations, there are still graduates who are not in accordance with their competencies in carrying out their duties or positions because they do not meet the requirements for competency development, and there are still many employees who roam during office hours so that the lack of employees is still less effective and efficient. Furthermore, how to develop employee competence is seen from the motives, character, selfconcept, knowledge and skills.

\section{METHOD}

In this study, researchers used a descriptive qualitative approach. Sources of data in this study were obtained through sources by conducting a question and answer session questions that fit the focus of the research. The data sources are Key Information, informants and research documentation data, in the form of photographs during the study. In this study using techniques and interview instruments, observations at the research location, and document review. Because the research conducted is qualitative then data analysis techniques are used, namely data reduction, data presentation and drawing conclusions and verification.

\section{RESULT AND DISCUSSION}

Makassar Raya Regional Region Company was established in 1999 which was marked by the ratification of Regional Regulation No. 4 of 1999 concerning the Establishment of PD. Makassar Raya Market, Makassar city.

\section{Competence}

Competence is a matter that is associated with the ability, knowledge / insight and attitude that is used as a guide in carrying out the responsibilities of work done by employees. Success 
that employees get. is the result of increasing employee competency while working in the Organization.

In this study what will be reviewed is the competence of employees in the Makassar Raya Makassar Regional Company. The results of this study are answers to questions raised by researchers to informants. The sub focus consists of motives, character, self-concept, knowledge, and skills.

\section{Motives}

Motives are impulses that move a person to behave because of the needs that want to be fulfilled by humans. Motive can also be said as a driving force from within to carry out certain activities in order to achieve a goal. The motive can be seen from the encouragement of economic needs and encouragement of social needs. Encouragement of economic needs can be seen from how to obtain welfare and comfort in doing a job, while the encouragement of social needs can be seen from the way of interacting with fellow humans in doing a job.

\section{Encouragement of Economic Needs}

From the indicators of the economic need boost in Makassar Raya Makassar Regional Market Company, the influence is very large and coupled with the achievement of revenue targets. And the results achieved must be followed by an increase competence that leads to an increase in the performance of every employee in the Makassar Raya Regional Market Company Makassar City

\section{Character}

The indicator of character is the character that makes people behave or how someone responds to something in a certain way. In addition to the competence of many organizations, they are more concerned with the character or personality of the prospective employee rather than their intelligence. A person's character is the most important element in carrying out a field of work in an organization. The trait is a character which is a form of way of thinking and behaving someone who will later become his trademark. While attitude is a person's feelings and thoughts in behavior when they don't like or like something.

\section{Self-concept}

Self-concept is attitudes and values measured through tests to respondents to find out the value someone has and what is interesting for someone to do something. The concept of self is the views and attitudes of individuals towards themselves. Self-views are related to how one's physical condition, individual characteristics and how to motivate yourself to determine and direct the development of personalities such as appearance and positive behavior. Appearance is anything related to human outward appearance that is easily observed and valued by other humans. While the behavior is an act/action and the words of someone whose nature can be observed, described and recorded by other people or people who do it. 
From the aspect of self-concept, employees who work at the Makassar Raya Regional Market Company in terms of appearance are already polite, maybe they should improve their language and behavior.

\section{Knowledge}

Knowledge is information that a person has in a specific discipline area specifically. Knowledge will be able to predict what a person can do, not what he will do. Because knowledge is a source of knowledge that can distinguish between what can be done well and right and what is wrong and there are still many individuals who use their knowledge for the wrong thing. Analytical thinking is a thought process that drives us to make better decisions. While information will give effect to one's knowledge. Even though a person has low education, if he gets good information from various media, it can increase one's knowledge

\section{Keterampilan}

Skill is the ability to do a certain task, both physically and mentally. Skills are the ability to use reason, thoughts, ideas in running or making things more meaningful so as to produce a value from the work. Administrative skills are the skills needed to succeed in the field of administrative work. While technical skills are abilities and knowledge needed to perform certain tasks.

\section{Discussion}

The role of human resources as a supporting factor for the success of an agency is very important. The development of an employee's competence can be one of the benchmarks of the success of the agency. Without the development of employee competencies, of course, an agency cannot achieve the goals it has set.Menurut (Amstrong \& Baron, 1998) mengemukakan bahwa kinerja merupakan hasil pekerjaan yang mempunyai hubungan kuat dengan tujuan strategis organisasi, kepuasan konsumen dan memberikan kontribusi pada ekonomi.

According to the opinion of Timple (Mangkunegara, 2003) that performance factors consist of internal factors and external factors, namely internal factors (dispositional), which are factors that are related to a person's characteristics. For example, a person's performance is good because they have high ability and someone is a hard-working type, while someone has poor performance due to those who have low ability and the person has no efforts to improve their abilities. And External Factors are factors that affect the performance of someone who comes from the environment. Such as the behavior, attitudes, and actions of coworkers, subordinates or leaders, work facilities, and organizational climate. According to the opinion of (Sedarmayanti, $2011,2017)$ argues that competence is a targeting characteristic possessed by someone who has direct influence on or can predict excellent performance. According to the opinion of (Silalahi, 2015) pengembangan sumber daya manusia adalah upaya berkesinambungan meningkatkan mutu sumber daya manusia dalam arti yang seluas-luasnya, melalui pendidikan, latihan, dan pembinaan.

According to the opinion of (Wilhelm, 1989) that human resource management as a function carried out in the organization with the aim of facilitating the effective utilization of human (employees) to realize organizational and individual goals. 
According to the opinion of (Becker \& Huselid, 2006) that competency refers to an individual's knowledge, skill, ability or personality characteristics that directly influence job performance. According to the (Sudarmanto, 2015) that competence is an attribute to put quality and superior human resources. These attributes are the qualities given to people or things, which refer to certain characteristics needed to be able to carry out work effectively. These attributes consist of knowledge, skills, and expertise or certain characteristics. According to the opinion of McCormick dan Tiffin (Riani, 2011) that there are two variables that can affect performance, namely the Individual Variable, namely Variables consisting of experience, education, gender, age, motivation, physical condition, personality and attitude. and Site Variable involves two factors namely Social Factors of the organization, including policy, type of training and experience, wage system and social environment and Physical and Occupational Factors, including work methods, settings, and conditions, work equipment, workspace settings, noise, irradiation, and temperature. According to the opinion of (Robbins \& Coulter, 2012), that competence is defined as a person's ability or capacity to do various tasks in a job, where this ability is determined by two factors which are intellectual ability and physical ability. According to the opinion of (Wibowo, 2007), that competence is defined as the ability to carry out or carry out a job or task based on the skills and work knowledge required by the job.

\section{CONCLUSION}

The results of this study indicate that the development of employee competencies as a whole is in a good category when viewed from the aspects of competence, motives, encouragement of economic needs, character, self-concept, knowledge, and skills.

\section{REFERENCES}

Alvesson, M. (2001). Knowledge work: Ambiguity, image and identity. Human Relations. https://doi.org/10.1177/0018726701547004

Amstrong, M., \& Baron, A. (1998). Performance Management. London: Institute of Personnel and Development.

Awaliah, N., Amirullah, A. H., \& Saleh, S. (2015). Kinerja Pegawai Negeri Sipil pada Kantor Kementerian Agama Kota Makassar. Jurnal Office, 1(1), 13-17.

Ayu, A., Niswaty, R., Darwis, M., \& Arhas, S. H. (2019). Applying the principles of Good Governance in the Efforts of Guiding Out-of-School Children at Social Service Offices Takalar Regency. Jurnal Office, 5(2), 51-58.

Becker, B. E., \& Huselid, M. A. (2006). Strategic human resources management: Where do we go from here? Journal of Management. https://doi.org/10.1177/0149206306293668

Carefoot, N. F. (1990). Human Resources Development. Water Supply. https://doi.org/10.4337/9781788113830.00020

Denhardt, J. V., \& Denhardt, R. B. (2015). The New Public Service Revisited. Public Administration Review. https://doi.org/10.1111/puar.12347

Erawati, I., Darwis, M., \& Nasrullah, M. (2017). Efektivitas Kinerja Pegawai pada Kantor 
Kecamatan Pallangga Kabupaten Gowa. Jurnal Office, 3(1), 13-18.

Gabcanova, I. (2012). Human Resources Key Performance Indicators. Journal of Competitiveness. https://doi.org/10.7441/joc.2012.01.09

Gupta, A. K., \& Singhal, A. (1993). Managing Human Resources for Innovation and Creativity. Research-Technology Management. https://doi.org/10.1080/08956308.1993.11670902

Gylfason, T. (2001). Natural resources, education, and economic development. European Economic Review. https://doi.org/10.1016/S0014-2921(01)00127-1

Mangkunegara, A. A. A. P. (2003). Manajemen Sumber Daya Manusia Perusahaan. In Remaja Rosdakarya. https://doi.org/10.1038/cddis.2011.1

Niswaty, R., Juniati, F., Darwis, M., Salam, R., \& Arhas, S. H. (2019). The Effectiveness of Leadership Functions Implementation in The Makassar Departement of Manpower. JPBM (Jurnal Pendidikan Bisnis dan Manajemen), 5(1), 1-10.

Osborne, S. P., Radnor, Z., \& Nasi, G. (2013). A New Theory for Public Service Management? Toward a (Public) Service-Dominant Approach. American Review of Public Administration. https://doi.org/10.1177/0275074012466935

Perry, J. L., \& Wise, L. R. (2006). The Motivational Bases of Public Service. Public Administration Review. https://doi.org/10.2307/976618

Pramularso, E. Y. (2018). Pengaruh Kompetensi terhadap Kinerja Karyawan CV Inaura Anugerah Jakarta. Widya Cipta - Jurnal Sekretari dan Manajemen.

Resources, H. (2011). Human Resources Management: Managing Employee Performance. Review Literature And Arts Of The Americas.

Riani, A. L. (2011). Budaya Organisasi (Cetakan Pe). Yogyakarta: Graha Ilmu.

Robbins, S. P., \& Coulter, M. (2012). Management. In Pearson.

Sanders, R. (2006). Introduction to human resources management. In Australian Library Supervision and Management. https://doi.org/10.1016/b978-1-876938-30-7.50019-0

Sari, W. P. I., Jamaluddin, J., Saleh, S., \& Arhas, S. H. (2020). Influence of Compensation on Work Performance in the District Office of Bissappu, Bantaeng Regency. Jurnal Ad'ministrare, 6(2), 105-114.

Sedarmayanti. (2011). Tata Kerja dan Produktivitas Kerja. In Bandung, CV Mandar Maju.

Sedarmayanti. (2017). Manajemen Sumber Daya Manusia. In Manajemen Sumber Daya Manusia.

Silalahi, U. (2015). Asas-Asas Manajemen. Refika Aditama.

Sudarmanto. (2015). Kinerja dan Pengembangan Kompetensi SDM. In Kinerja dan Pengembangan Kompetensi SDM.

Sung, S. Y., \& Choi, J. N. (2014). Multiple dimensions of human resource development and organizational performance. Journal of Organizational Behavior. https://doi.org/10.1002/job.1933 
144 Jurnal Administrare: Jurnal Pemikiran Ilmiah dan Pendidikan Administrasi Perkantoran

Volume 6 Number 2 July- December 2019. Pages 137-144

Wibowo. (2007). Manajemen Kinerja. Jakarta: Raja Grafindo Persada.

Wilhelm, P. G. (1989). Controlling Work Stress: Effective Human Resource and Management Strategies. Academy of Management Review. https://doi.org/10.5465/amr.1989.4279083 